\title{
Local French Food Initiatives in Practice: The Emergence of a Social Movement
}

\section{Angela Giovanangeli, University of Technology, Sydney}

France has the highest density of large-scale food retailing per capita in Europe with familiar names like Carrefour, Leclerc, Auchan and Casino ingrained in the French hypermarket landscape. ${ }^{1}$ In 1996, then president Jacques Chirac made a televised statement describing the mass-market food industry as a 'purely French phenomenon' while adding that it was detrimental to French society. ${ }^{2}$ Chirac refers here to the effects of large-scale marketing systems on consumption. Large retailers are influential in the choices people make with regard to food: they control the price of food; they also decide what type of food is placed on retail shelves. A few years later in 2000, in a tellall book on large-scale marketing in France, the economist Christian Jacquiau supported this claim in his description of the system of mass food marketing in France as an economic dictatorship (2000: 25). For Jacquiau food retailing raises ethical, political and cultural issues with regard to the way large-scale industries dominate food distribution, consequently affecting what farmers are able to produce and how consumers choose what they eat.

Chirac's warning seems to have made little impact in reducing the number of hypermarkets in France today. However, over the last decade food producers in France

\footnotetext{
${ }^{1}$ Hypermarkets are generally defined as superstores that combine the functions of supermarkets, other forms of food and specialised retailing, and department stores. In France there are 1.5 hypermarkets for every 100,000 inhabitants, compared with Germany and the United Kingdom which have 1.3, Belgium which has 1, Spain 0.3 and Italy 0.2 (Jacquiau 2000: 363).

2 Televised on the French television channel France 2 on May 11996 (Jacquiau 2000: 226).
}

PORTAL Journal of Multidisciplinary International Studies, vol. 10, no. 2, July 2013.

Edible Alterities: Perspectives from La Francophonie Special Issue, guest edited by Angela

Giovanangeli and Julie Robert.

ISSN: 1449-2490; http://epress.lib.uts.edu.au/ojs/index.php/portal

PORTAL is published under the auspices of UTSePress, Sydney, Australia. 
have been increasingly vocal in identifying the tensions that exist between large food industrialists and local producers. The strain French farmers are feeling in the agricultural sector as a result of product price falls and the forgotten importance of local food can be seen, for example, in the anti-multinational activism of José Bové in the late 1990s (Bové \& Dufour, 2000: 77-78), the 2010 French farmer protests in Paris (Davies 2010), and the 2012 wave of supermarket bombings in Corsica, opposing the implantation of hypermarkets on the island ('Sept supermarches visés’ 2012).

Fifty years after the introduction of large-scale food marketing in France, some food producers are initiating change in how food is exchanged between consumers and producers. Some farmers in France are bypassing large-scale markets and supplying food directly to local consumers. Cooperatives connecting producers to consumers are surfacing across France and underscore the resistance of farmers to large-scale distribution. Goodman's research on alternative food networks suggests that 'local food provisioning is depicted as a site of "resistance" to the anomic forces of a globalizing corporate food system and against further incursions of placeless, homogenized foods and standardized gastronomic practices' (2010: 193). The sociologist Starr goes so far as to suggest that local food initiatives are coalescing into a new form of social movement that is challenging the existing food distribution system. She argues that these initiatives are a form of social change that is transforming food from a commodity to a community (2010: 479).

Drawing on these notions of resistance and social change, this paper investigates some of the developments in France with regard to the distribution of food and examines the case of a French farm market. Recent literature on 'alternative,' local and 'quality' food networks as new economic and cultural activities are often framed within the context of English speaking countries (Beardsworth \& Keil 1997; Allen et al. 2003; Winter 2003; Kneafsey et al. 2008; Peters et al. 2008; Starr 2010). Much of the US academic literature on food activist discourse makes a strong connection between the localisation of food systems and the promotion of environmental sustainability and social justice (DuPuis \& Goodman 2005; Starr 2010). This paper seeks to redress the limited attention given to local food activist discourse in France and explores the possibilities afforded by the adoption of a social movement approach to the case study of a French farm market. As a Western industrial state that has similar agricultural patterns to other Western 
countries, France is a significant player in international trade agreements and representative of European powers in the world economy (Barham 1997: 239-40). A better understanding of French local food initiatives can thus be useful for understanding social movements in Western countries in the area of local food discourse.

\section{Theoretical framework}

Social movement scholars such as Chesters and Walsh argue that social movement theory continues to be debated within sociology and other disciplines (2011: 2, 21). This is unsurprising given that many concepts, schools of thought and disciplinary frameworks animate social movement studies, and social analysts disagree about the very definition of social movements (Staggenborg 2011: 21, 8). Theorists like Tilly and Wood view social movements as a form of contentious politics that promote a political view (2013: 3-4). Similarly, Tarrow defines social movements as 'collective challenges, based on common purposes and social solidarities, in sustained interaction with elites, opponents, and authorities' (1998: 4). Social movement scholars have recognised that 'movements consist of more than politically motivated organizations with an explicit mandate to seek change in public policy' (Staggenborg 2011: 7). Staggenborg’s work suggests that social movements are not limited to politically centred enterprises, and that 'movements such as religious and self-help movements tend to be neglected along with less visible forms of collective action, such as efforts to change institutions and create new forms of culture (7). Similarly, Snow's work argues that movements can be conceived as ‘collective challenges to systems or structures of authority,' including different types of organisations and institutions and also sets of cultural beliefs and understandings (2004: 4). While definitions of social movement may vary, they also share some common ground, notably in describing social movements as an attempt to bring about social change (Staggenborg 2011: 8) and to produce knowledge (Chesters \& Walsh 2011: 20).

Within the context of local food initiatives, the use of culture as a lens to describe and analyse social movements may provide a basis for understanding spaces and practices of food consumption and distribution as a site of collective action. Johnston's research on social movements and culture extends the scope of how a cultural perspective can inform social movement analysis. This work relates how 'culture can be applied readily to social movements insofar as participants often hold values, attitudes, beliefs, and 
ideological orientations that are often quite distinct form the broader culture and that shifts in belief cause social change '(Johnston 2009: 4). While the concept of culture is 'complex and fluid' (4), the cultural approach to studying social movements takes into account how culture is played out in social performance or social action, stressing the 'agentic and collective aspects of culture' (5). A cultural perspective conceptualises social movements as performances and 'locates culture in the interaction among participants, firmly grounding culture in its collective enactment '(8; see also Johnston \& Klandermans 1995: 13). For Johnston 'performances are encounters to which social actors bring their ideas about how the world is or should be, offering them up to social discussion' (2009: 26). A performative view of culture stresses that social movements are not just shaped by culture; they also shape and reshape culture itself (Johnston \& Klandermans 1995: 9). Johnston distinguishes between specific processes of meaning construction in the context of performances, including oppositional, narrative and cultural performances.

In the context of social movement theory, this approach provides a compatible means of analysing and understanding the local food market as a cultural space of collective action. First, as Johnston notes, oppositional performances imply that the 'inherent oppositional quality of culture penetrates to the heart' of the social movement field with cultural performance 'played out by individuals who experience and produce meanings that they almost always perceive as incomplete in comparison to the community's template' (2009: 10). Johnston here is referring to the new ways or ideas a community or a group of people may have in interpreting specific issues within society (2009: 10). Second, narrative performances involve common elements of culture whereby the 'narratives figure into basic mobilization processes creating collective identity, collective memory and organizing relations’ (13). Narratives can be used to tell a story and that the story's 'moral points assume shared norms and values-these narratives may help the social movement analysis with stories that attract participants and maintain solidarity (14) and allow the audience to construct meaningful connections to themselves. Finally, cultural performances refer to the ways new ideas or innovations are constructed within society, with the aim of bringing about cultural change. Johnston therefore views culture in the context of these performances as a community of people who view a specific issue in new ways. These principles can be used to describe certain cultures as sites of resistance, which are situated within larger cultural networks (9). 


\section{Food and public discourse}

Work by Kneafsey et al. (2008: 7) and Beardsworth and Keil (1997: 158) suggest that there is a strong sense of disconnection between food producers and food consumers. The industrialisation of the food system means that food production and processing increasingly take place beyond the view of the average food consumer, involving techniques that he or she is only vaguely aware of or simply does not understand. However Kneafsey et al. also point out that 'disconnecting' trends in the food system are opening up co-evolving spaces or spaces of 'reconnection' between certain producers and consumers of food (2008: 7). Indeed, alternative food initiatives are appearing in many places. Some of the literature in the USA and the UK suggests that these initiatives have a political agenda as oppositional sites to structures that coordinate and globalise the current food system while seeking alternative ways of producing and distributing food so that it is environmentally sustainable, socially just and economically viable (Allen et al. 2003; DuPuis \& Goodman 2005; Goodman 2010; Sage 2003; Starr 2010). DuPuis and Goodman's work considers the European alternative food networks in the USA and Europe and highlights the distinction between US and European local food discourses. They argue that in the USA, the driving force in the creation of alternative food systems is a concern for local food system care ethics and sustainable farming, whereas European local food movements appear to stem from a perceived need to protect the European rural economy and society from the potentially damaging consequences of international agricultural trade liberalisation (DuPuis \& Goodman 2005: 363). Tregear’s observations on alternative network research highlights the complexities of the topic and reveals that terms such as 'alternative food network' are problematic because they are used to describe food systems that are somehow different from the mainstream, hence defining what 'the phenomenon is not, rather than what it is' and covering an array of producer/consumer connections such as localised and short food supply chains, farmers’ markets, community supported agriculture and community gardens and organic schemes (2011: 423).

The emergence of alternative food economies in France may further be understood in relation to the overlapping dynamics of Europeanisation that have shaped the relationship between food production, distribution and consumption bringing food to the fore as a focal point in debates around attachments to locality and national identity in a globalised epoch. 
In 1962, the Common Agricultural Policy (CAP) set out the European Union’s (EU) legislation and practices in the area of agriculture. The CAP's initial aims were to increase agricultural productivity (European Commission 2012). Since 1992, however, the CAP shifted its policies and focus from providing support to the market and the idea of productivity to one that recognises the central role of food producers or the 'multifunctionality' of the farmer who is more than a producer of food but also someone who is concerned for other areas such as the environment and the community. Goodman's work supports that local food initiatives have been among the beneficiaries of the continuing process of reform of the CAP but he goes further in stating that these reforms respond to the trade liberalisation mandate of the World Trade Organization (WTO) that prioritises non-production related payments, such as environmental schemes. Goodman argues that these programs, by de-coupling farm payments from production, are gradually re-orientating the CAP away from its narrow, sectoral focus towards a more decentralised model in which a multi-functional agriculture is the centre-piece of a 'more pluralistic, integrated and endogenous approach to rural development' (2010: 190-91).

Bowen and De Master's fieldwork attempts to demonstrate that 'in recent years, the EU's stated commitment to the principle of multi-functionality within its Common Agricultural Policy has fostered a resurgence of interest in recovering and protecting the heritage and traditions associated with local agricultural products,' adding that some 'initiatives seek to counteract homogenization and the increasing loss of species diversity in global agriculture by protecting heritage breeds of domestic livestock and heirloom seed varieties’ ( 2011: 73). These approaches show the significance territory and food are playing as a result of European competitiveness in the global market, with policies that may encourage farmers to emphasise the local origin of their food in order to distinguish themselves from other products on the market. In the French context, the concept of terroir further highlights the link between territory and food. While the term terroir refers historically to an area or terrain, 'whose soil and microclimate impart distinctive qualities to food products,' in recent years, the term terroir also 'reflects a conscious and active social construction of the present by various groups concerned with rural areas in France (social and economic organizations, state agency personnel, academics),' who strive to 'recover and revalorize elements of the rural past to be used 
in asserting a new vision of the rural future' (Barham 2003: 131). As such, the concept of terroir is charged with both cultural and political connotations.

Potter and Tilzey describe however the complexities of the EU's CAP policies. They state that on the one hand CAP policies promote a neoliberal approach emphasising the primacy of international and global markets and on the other develop an approach that sets limits to 'laissez-faire through selective market protection and support, social welfare legislation, labour standards and a concern to preserve social consensus’ (2005: 588). For Potter and Tilzey this framework is highly contested in the sense that 'support for liberalization and multi-functionality are contradictory and irreconcilable' (592) and raises questions on how to defend local farming spaces that are increasingly integrated into the wider circuits of the industrialised agro-food system (596).

\section{Cultural and collective resistance in France}

In France since the late 1990s food activists and thinkers have created narratives questioning the way food is produced and consumed. For instance, in 1999 the sheep farmer and anti-multinational corporations activist José Bové and other members of the agricultural union Confédération Paysanne ‘dismantled’ a McDonald’s restaurant under construction in south-west France. In part their aim was to protest against the US domination of the French food market, but the action also hoped to draw attention to changes in French eating habits and taste (Willging 2008: 200). In the 2000s Bové's public campaigning in defence of local farmers' rights and small scale food production has been complemented by co-authored publications on the topic of local food and food activism such as Nous, Paysans (Bové \& Luneau 2000), Le Monde n'est pas une marchandise; des paysans contre la malbouffe (Bové \& Dufour 2001), Paysan du Monde (Bové \& Luneau 2002), La Confédération paysanne (Bartoli, Bové \& Manguy 2003) and Changeons de cap, changeons de Pac: Vers une agriculture paysanne au service des citoyens (Bové \& Luneau 2012). Willgang’s analysis of Bové’s discourse as articulated in media interviews reveals Bové's concern with contemporary food trade involving national culinary autonomy and particularism as well as consumer safety. Willigang points out that Bové captures through his discourse the ambiguity and subjectivity of what we understand food to be, and consequently invites the public to take a position with regard to their own interpretation of food consumption and distribution (Willgang 2008: 206). 
Similar narratives are also found in the discourse of French philosopher Michel Onfray. In 2006, Onfray set up a popular university of taste in Argentan, northern France, l'Université Populaire du Goût d'Argentan. The university's website is testimony to the narrative that Onfray develops regarding the notion of food. His university 'propose aux gens de toutes conditions d'apprendre à retrouver le goût des choses ${ }^{3}$ and does this by offering to the public free seminars and activities led by food experts on the importance of local food as well as discussion on the art of cooking (Université Populaire du Goût website). Through the university's website Onfray describes the story behind the university's creation. The university of taste was set up in response to a friend who prepared baskets of freshly grown market food produce for marginalised people: former prisoners; drug addicts; and alcoholics. The friend was dismayed to find that the baskets were rejected in preference for frozen and processed food. Consequently, Onfray's response was to establish his university in order to inform people of the role of food in society, and of the connection between local food, taste and lien social or social ties and community. According to Onfray, the aim of his university is to remind people of these links.

While the work of Bové and Onfray are not directly connected to each other, the narratives are similar and tell of their opposition to the dominance of large-scale food marketing, which they see as models of consumption based on unhealthy and unethical production methods that compromise taste and favour culturally anonymous foods. Bové and Onfray are not alone in their concern for the food that is available to the public. Independent cooperatives in the form of farm initiatives have emerged in France and show signs of resistance to large-scale marketing distribution systems. Farm markets have historically been a common feature in France with market sellers vending food produce in town squares and local producers selling directly from their farms. Indeed, Kneafsey et al. note that local products in fact trade on their historical associations with particular places (2008: 30). Moreover, Zimmer informs us that French food cooperatives linking producers to consumers date back to 1793 and continued into the 1970s with many of them disappearing in the 1980s when they could no longer compete with the low prices of mass distribution (2011: 54).

\footnotetext{
${ }^{3}$ Invites people from all backgrounds to rediscover the taste of things. This and all subsequent translations are my own.
} 
Alternative farm markets, however, are emerging as sites of production that present new ideas about how food is exchanged. They have appeared in response to large-scale food distribution and attempt to reconnect producers and consumers in order to allow local farmers to survive beyond the limits of mass distribution. For instance, in 2001, the Association pour le maintien d'une agriculture paysanne (AMAP), an association in support of local agriculture in France, was launched in the south west of France. ${ }^{4}$ The aim of AMAP is to bind local producers and consumers through a contract in support of local agriculture. AMAP members take turns to go to farm markets and to distribute baskets of produce to other members. When the initiative first began, the first baskets were empty and were a symbol of the support individuals were willing to give to local agriculture ('Les Amap’ 2012: 18). The fact that these first baskets were empty underscores the idea that members were interested as much in local food distribution inequalities as they were in the type of food they were purchasing. AMAP's website homepage state's that the association's aim is to 'favoriser l'agriculture paysanne et biologique qui a du mal à subsister face à l'agro-industrie' (Association pour le maintien d'une agriculture paysanne website). ${ }^{5}$ The page also emphasises the importance that AMAP attributes to the link between consumer and producer; as it states in bold: 'le principe est de créer un lien direct entre paysans et consommateurs. ${ }^{6}$ In a paragraph outlining the reasons why consumers participate in this initiative is rhetoric that connects the health benefits of eating local [la santé] to the civic duties of the consumer or 'citizen's action' to support the work of the local farmer [action citoyenne: soutenir directement un agriculteur local] (Association pour le maintien d'une agriculture paysanne website). According to Zimmer's work on this initiative, there are now as many as 100,000 actors involved in AMAPs throughout France and this figure has steadily been increasing over the last few years (2011: 48). More recently, in 2012 another local food initiative entitled Drive Fermier began operating. ${ }^{7}$ Located in the Bordelais region, the aim of this drive is to once more connect local producers to consumers and, more specifically, to challenge the large-scale industry's concept of supplying food quickly and inexpensively by providing consumers with traditional produce direct from the farm within hours of orders being placed online. The homepage of the initiative states: 'Plus de kilomètres superflus, de temps perdu, de caddies,

\footnotetext{
${ }^{4}$ Association for sustaining farm agriculture.

${ }^{5}$ help farmers struggling to compete with industrialisation.

${ }^{6}$ the aim is to create a direct link between farmers and consumers.

${ }^{7}$ Farming Drive.
} 
d'impatience aux caisses et de mal aux reins ... Ensuite, vous n'aurez plus qu'à remplir votre frigo, cuisiner et déguster en famille ou entre amis, les VRAIS «Produits de Gironde»' (Drive Fermier website). ${ }^{8}$ These ideas oppose aspects of the hypermarket structure — such as lost time, fatigue and artificial food-emphasising rather the initiative's advantages of time and convenience while highlighting the connection between quality food and local produce.

These examples demonstrate that changes are currently taking place in the way that food is understood and distributed to consumers in France and that alternative discourses and collective initiatives are challenging the large-scale food marketing industry. While these initiatives work independently from each other, they share a common historical relationship in the sense that they respond to the large-scale industrial structures that have not only disconnected producers from consumers but have also disempowered local farmers in the choices they make with regard to food production and pricing. While similarities in the aims of each initiative are evident, this paper seeks to examine the individual practice of a local French market in order to understand the narrative the producer constructs within the context of a wider collective action.

\section{Background of case study}

Evidence presented in this paper draws from fieldwork that took place in April 2012 at La Cassole farm located in the commune of Saint-Didier-de-la-Tour, 55km from the city of Lyon, in south-eastern France. ${ }^{9}$ The farm's regional location has a special relationship with food. In the early 1900s Lyon was recognised as a gastronomic city thanks largely to the quality and variety of its local food products. In 1925 the French gastronomist Curnonsky proclaimed Lyon the world capital of gastronomy. Today the region has over 30 products that have regional culinary heritage classification.

The primary aim of my research is to examine the objectives and evolution of the farm market in the context of the increasing number of local food initiatives in France. This work prioritises cultural performance of the local farm initiative as a basis to understanding collective action in local farm market initiatives. Semi-structured

\footnotetext{
${ }^{8}$ No more superfluous kilometers, wasted time, trolleys, waiting in queues and sore backs. All you need to do is fill your fridge, cook and share with your family REAL produce from the 'Gironde area'.

${ }^{9}$ Population 1,742 according to 2009 estimates of the French national statistics institute (INSEE).
} 
interviews were conducted with the founders of the La Cassole market, and participant observation took place with some of the actors involved in the weekly market.

Questions focused on the motivations and the opinions of these producers with regard to their work and their relationship with consumers. It was important, however, during this observation not to idealise the countryside and the customs defined as central to rural identity. For the producers of the farm market, the market is central to their livelihood and is above all a commercial enterprise. I examine this case study from the perspective of local food producers who hold a weekly market every Friday evening on La Cassole farm. The term local food is used to describe food purchased directly from small farmers, produced seasonally and exchanged in a context of community. The term 'producer' is used here to refer mainly to farmers who grow crops and raise livestock. Using the word producer, however, can be problematic because producers can also be consumers, and on the farm I witnessed the producers selling their products but also purchasing food from each other.

La Cassole farm is owned by Karen and her husband Frédéric. Frédéric is from a farming family. His grandfather purchased the land of the present farm from a local landowner in the 1920s and transformed it into a dairy farm. Frédéric studied at a French agricultural college and took over from his father in the early 1990s. The 45 hectare farm has 28 cows. Karen has no background connection to the agricultural sector and became involved in the farm market around 2009 when the family decided to set up the farm market on the site of the dairy farm.

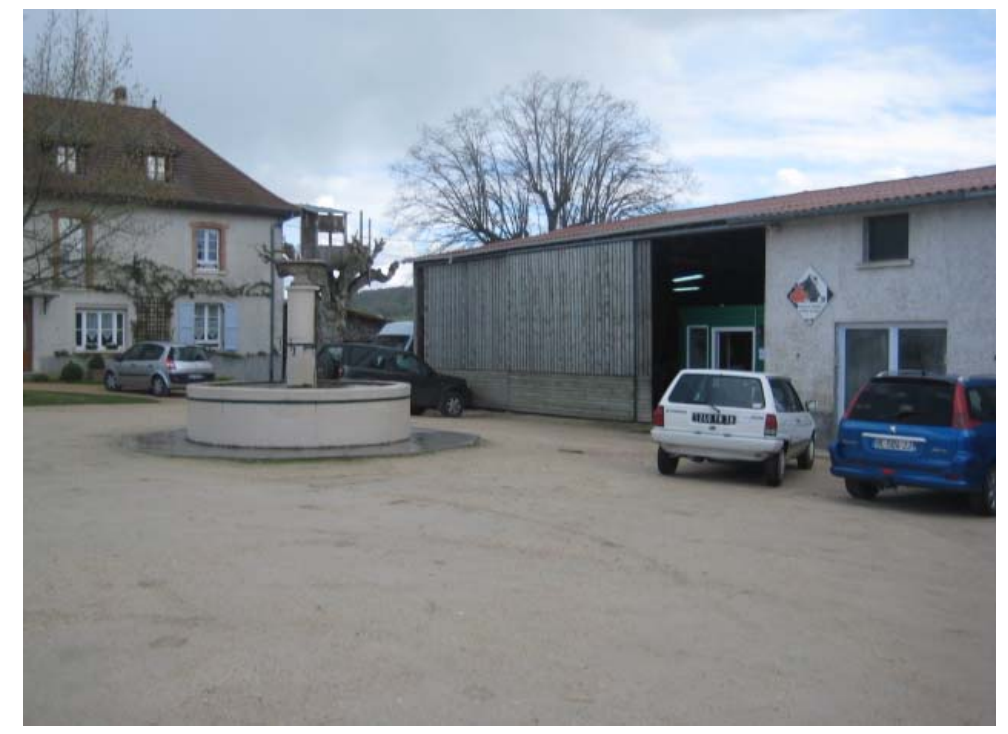

Figure 1. La Cassole farm on market day (C) A. Giovanangeli. 


\section{Opposition to mass-market food distribution relations}

Traditionally la Cassole farm has been producing milk that is sold to one of France's leading dairy processors and distributors. The milk sold to this group is processed into commercial dairy products that are then sold to large-scale market systems. In 2009, Karen took an active part in the farm's activities when she set up a weekly local market alongside the farm's traditional activities. Karen notes: 'My background is not in farming but I became involved in the farm market when the dairy production of the farm was struggling to make financial profit. In 2009 the crisis in the dairy industry affecting EU countries, including France, as a result of an overproduction of milk pushed milk prices down dramatically. ${ }^{, 10}$ Indeed in 2009 prices of milk produced in EU countries fell by 36 per cent ('EU calls milk crisis meeting’ 2009). Karen points out: 'This fall in milk prices and the ensuing disputes between farmers, distributors and processors forced many farmers into unsustainable living conditions and bankruptcy. In order to compensate for the dramatic fall in our salaries, we began selling milk directly from our farm in order to make ends meet.' Karen adds:

Today many dairy farmers are either selling their land or doubling their livestock in order to produce more milk...doubling the number of cows however costs more in terms of feed, care and equipment....another alternative is to take on extra activities on top of the usual farming like the farm market which farmers have been increasingly adding to their farm activities in our area over the last few years...the advantage of this type of market is that the middle man is cut out and the farmer is in charge of his/her livelihood.

This narrative is similar to the discourse in Goodman's research that describes how alternative food provisioning networks 'promise relief from the oppressive cost-price pressures on farmers exerted by ... the market power of oligopolistic retail multiples, with their harsh, exploitative techniques of supply chain management’ (2010: 191). Goodman also relates that these networks provide farmers 'opportunities for more diversified farm livelihoods' (191) that help create a more viable economic enterprise.

Since setting up the farm market, Karen and her husband have also learnt to make yoghurt, soft cheese and cream. In addition to these activities, they have invited 7 other local producers to set up stalls in the barn of the farm adjacent to the farm's milking activities. Karen points out the importance of producer networking and local food: 'By inviting other producers to share the farm space on a market day we are able to attract

\footnotetext{
${ }^{10}$ Original interviews were conducted in French at La Cassole farm in April 2012. The English translation of these interviews are my own.
} 
more consumers by offering more choice. Not only do we provide milk that comes straight from the dairy but we also have producers who sell bread made from local grains, meat, cheese, poultry, wine, fruit and vegetables.' Karen stresses that the produce comes predominantly from the commune with the exception of one producer who travels 70 kilometres to provide fruit that is not locally grown in the area in order to add to the variety of produce on offer. Around 80 to 100 consumers aged between 30 and 75, come to this farm each week and are mainly locals living within a 10 kilometre radius of the farm.

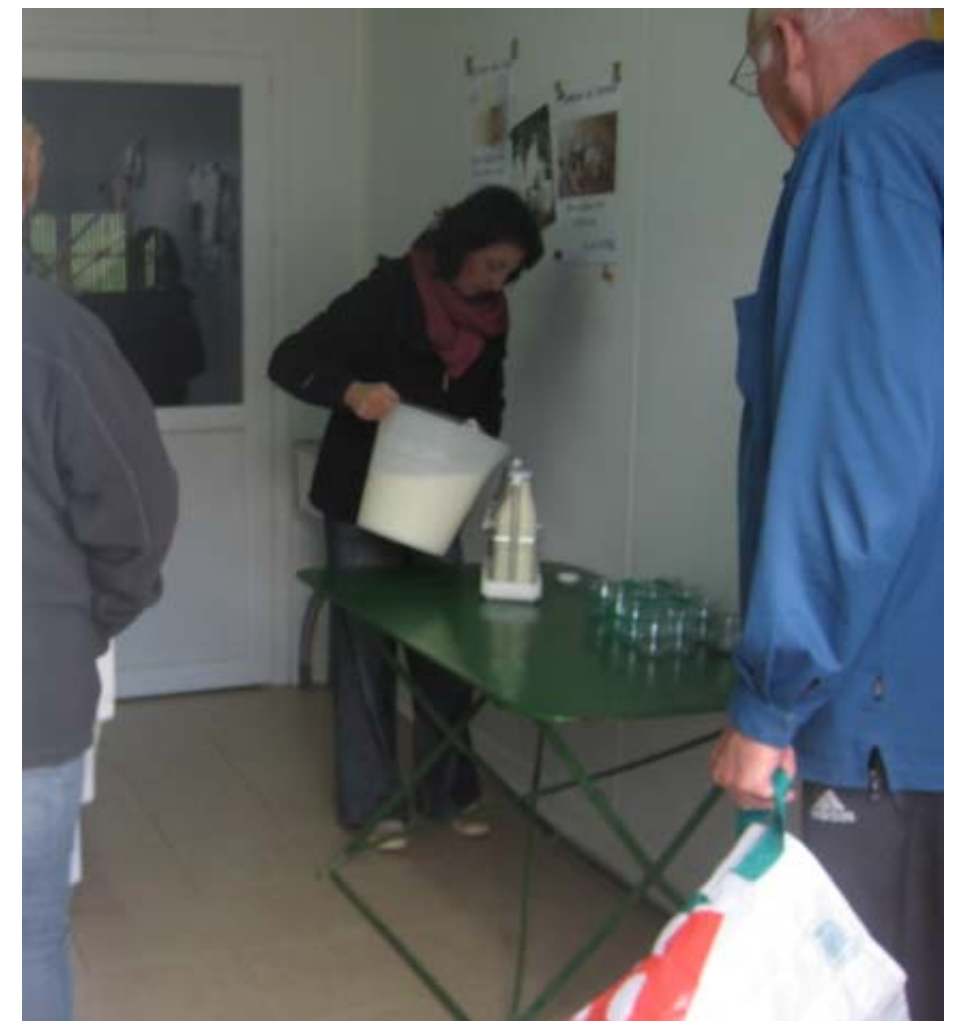

Figure 2. The dairy section of the farm market (C) A. Giovanangeli.

Karen and Frédéric describe some of the general struggles of local farmers in their area who wrestle to compete with the increasing industrialisation of food distribution. For Karen and Frédéric, working as a collective group in a farm market strengthens their existence as farmers. They acknowledge that some farmers in their area have attempted to provide local produce on their own but often struggle with finding customers willing to come to their farm for one type of product, as a collective the initiative has a better chance of succeeding. Karen observes that some of the farmers in the local area have gone to great expense to find ways to resist large-scale marketing structures. She explains: 
In 2009 some local dairy farmers went as far as installing expensive vending machines in key town locations...in front of the bakery for example where people pass by daily. Each day the farmer would deliver fresh milk from their farms to these machines, the vending machines each cost 45,000 euros but they did not succeed in attracting consumers to the milk, unlike our farm initiative, where the numbers of people coming have grown steadily.

For Frédéric selling his milk directly to supermarkets is out of the question because he feels he was exploited by the large industrialists when the milk prices fell in 2009. Allen et al.'s work suggests that locally situated alternative food initiatives are 'framed as counter-movements that challenge the control of corporations and other national and global institutions and resist the ecologically and socially destructive practices of the contemporary global agrifood system’ (Allen et al. 2003: 63). This attempt to resist industrial food distribution systems does come at a price for some farmers, as Karen notes: 'not all farmers have been as fortunate as us in making the farm market work ... some farm market initiatives have failed. Our location near a main road has helped make us successful ... as well as the variety of food we are able to offer through our network.'

The farm market signifies for producers a more sustainable way of earning a living. By bypassing large industrial groups, the producer is able to sell a product for considerably more when selling directly to consumers. Karen stresses this point when she notes:

Our milk sold at the farm market is the same price as the milk sold in supermarkets. For us this means a huge increase in the amount of money we earn - the milk sold directly to consumers on one local market day earns us the same income as the milk we produce in one week for the large industrial group that is our original source of income, when you think about it, our market revenue now earns us more than our main activity. For example in 2011, 45,000 litres of milk sold at the market made us as much money as 280,000 litres sold to the big industrial group ... with the farm market we have the freedom to do what we want and to sell at the price that suits us, with the prices set by industrial groups our livelihood is precarious and relies on pricing made by external parties.

Karen's concerns underscore the huge profit margin of the mass distributors and the restrictive forces placed on farmers when they rely on large food distribution systems. This notion is echoed in the work of Winter examining local food networks in the UK. Winter argues that in the

global food system, power rests with those who can structure this system by spanning distance and decreasing time between production and consumption ... Localism becomes a counter-hegemony to this globalization thesis, a call to action under the claim that the counter to global power is local power. In other words, if global is domination then in the local we must find freedom. (2003: 361) 
This freedom is achieved not only in pricing but also in how the farmer situates his role in the agricultural sector. For Frédéric, choosing to not solely limit his production to large industrial groups is also a response to the way the farmer is valued in the food sector. In his role as a dairy farmer selling to a large dairy industrial group, Frédéric describes how his milk is collected each week by trucks that come to the farm. Feedback on the quality of his work is sent to him only if the milk's quality is not deemed satisfactory. Frédéric explains: 'When the milk’s quality is more than satisfactory I don’t receive any comments complementing my work from industrial companies. Since the creation of the farm market, I feel valued as a farmer for the quality of my work.'

During my visit to the farm market, I witness consumers approach Frédéric on numerous occasions to tell him how much they appreciate the quality of his dairy products and to ask him questions related to his expertise in food production. This response is consistent with studies on the growth of face-to-face transactions as sites of opposition to the mainstream food industry. For example, Sage's work on 'Social embeddedness and relations of regard' argues that the producer of local food who sells in person 'acquires a more intimate acknowledgement of their expertise and of the trust that is bestowed upon them,' and through building a closer relationship with local consumers 'this legitimizes the social embeddedness’ of local food produce (2003: 53). For Sage, social embeddedness conveys 'principles of social connectivity, reciprocity and trust, characteristics’ particularly in areas such as direct agricultural markets (47). Indeed, Frédéric admits that connectivity to consumers has given him the desire to innovate and experiment with other milk derived products such as yoghurts and soft cheeses, something he admits he would not have been able to do working solely with a mass distributor. This practice contrasts sharply with the demands of large-scale marketing systems that encourage high productivity and uniformity pushing growers to sacrifice flavour in the production process (Ekelund \& Jönsson 2011: 444).

\section{Farm market narratives}

For Karen and Frédéric the rural is central to their identities and both expressed a strong sense of care about food production and the geographical area of their community as a result of their social connection to local consumers. Involvement in the local market has meant, however, that in addition to identifying with the role and place of farmer or food 
producer, Karen and Frédéric have had to become something more than food producers. This highlights the multi-functionality of farmers mentioned earlier in the EU context, and the way that farmers play complementary roles within society that go beyond the role of food producers. Karen and Frédéric have attempted to reconnect with consumers: not only do they produce food, but they also inform customers about their produce and it is through this information that they are able to create narratives that promote a collective identity enabling consumers to construct meaningful associations with regard to the food that is consumed.

Food in the context of the farm market is viewed as a community rather than a product, a notion observed also in the work of Kneafsey et al. (2008) in the context of local UK food initiatives. Karen stresses this sense of community on a number of occasions when talking about what the farm market means to her and how she communicates with her customers:

Before the farm market began, I didn't know quite as many people ... I've gotten to know many of them quite well now ... we all live a few kilometers from each other ... I have noticed that talking to people about our produce and our farm has created links not just between me and the customers but between the customers themselves.

The community is seen as an organisation of human relationships offering a new system. I observe this sense of community at La Cassole farm through the various relationships that exist between the producer and the consumer. The farm offers an alternative space to the supermarket, small grocer or street market in France. During La Cassole’s market day, I watch as Karen discusses daily matters with her customers while serving them. Some of the conversations are banal and refer to daily events. Other discussions are quite intimate: a woman speaks of her 21 year-old daughter who has run away from home not leaving an address; another woman discusses her work as a ceramicist; and yet another woman is quite critical of the work of local politicians. In line with Massey's view on space, the farm may 'be seen as the product of interrelations, and as a sphere in which distinct trajectories coexist' (2005: 11). This highlights the production of locality and the ways in which this opens up the very space of 'reconnection' between food producers and consumers so that the local becomes the focus of the narrative within the context of food (see also Kneafsey et al. 2008). The farm therefore is a space in which to communicate and share perceptions of experiences, where intimate association encourages collective identity, shared grievances and a creation of networks. This 
narrative of community and locality is not confined to the weekly market day but continues in other ways. For instance, the farm has hosted open days on which families are invited to visit the farm to get a glimpse of how the dairy farm works. Visitors are invited to ask questions and to look at the machinery and techniques used throughout the farm’s working week. Karen and Frédéric have also opened up their home to customers for screenings of documentaries on local food debates as well as sessions with guest experts on specific local food produce.

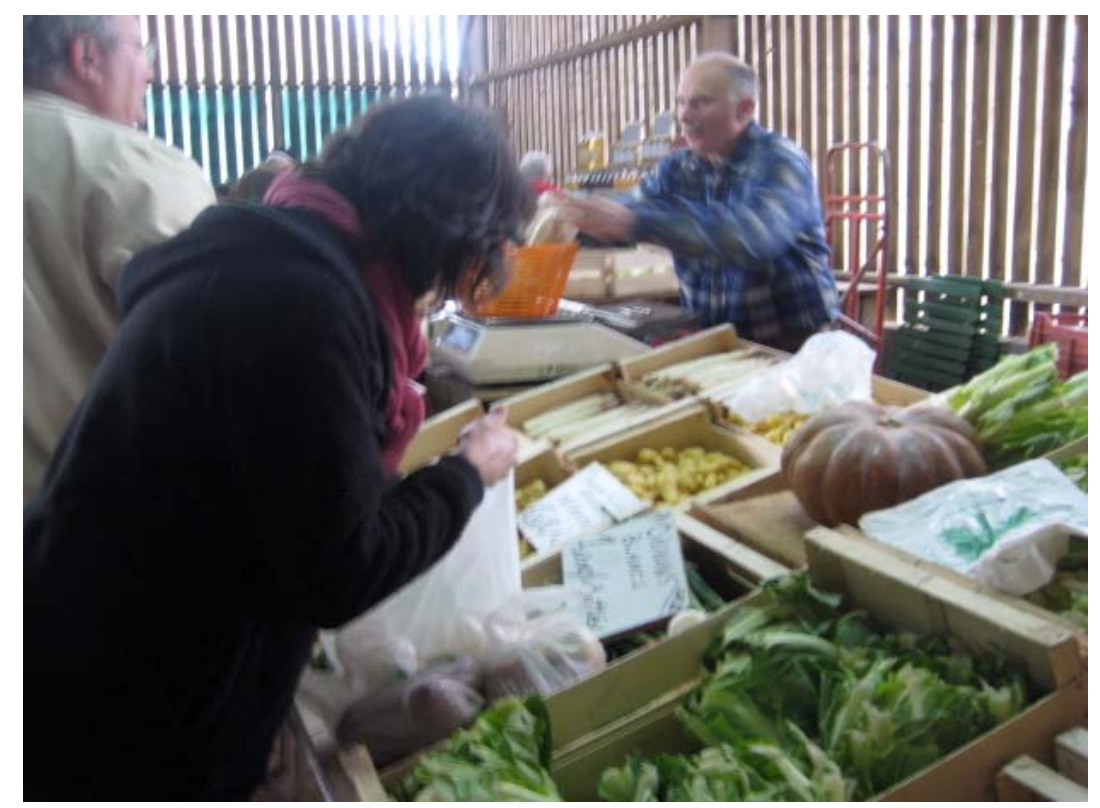

Figure 3. Food and narrative at La Cassole farm on market day @ A. Giovanangeli.

Technology such as the Internet has further contributed to the local food narrative associated with the farm market. A website set up by Karen in 2009 outlines the origins of the farm, the open days held at the site of production and the weekly events of the market (La Cassole farm website). The farm's website also provides detailed pictures and explanations of the farm's work. Customers are able to obtain a sense of connection with the food that they buy as well as product transparency in the techniques used and official norms applied. The internet is also used to communicate directly with consumers. Karen sends regular group emails notifying customers of the seasonal availability of certain products. When I visited the farm in April 2012 consumers made a point of saying that the email reminder allowed them to know that the first strawberries of the season had arrived. As a result of these factors, the meaning given to food in this farm market shifts from predictability and standardisation to locality, diversity, and seasonality. 


\section{Cultural performances: new ideas and shared knowledge}

The farm market supports relations between consumers and producers and Karen is aware of the new performative identity the local farm has given her and her husband as entrepreneurs, traditional farmers, providers of knowledge and as ecologists who are valued for their work. To use Johnston's term, these 'cultural performances' create a new dialogue between local farm producers and consumers. The local farm producer brings to the dialogue new ideas about how food production and distribution is, or should be, subject to social discussion (Johnston 2009: 26). At La Cassole farm, Frédéric is not only the producer of dairy products; he is also a source of expertise and a sharer of knowledge. On market day he discusses with consumers the type of feed that is given to the cows at his farm, explaining that he uses hay that is not fermented because it is better for the cows in terms of their life span and immune system. Posters decorate the walls of the area occupied by customers on market day, elaborating on the homeopathic methods Frédéric uses to treat his cows when they are unwell and the advantages of this treatment on both the quality of the milk and the health of the animals. Information flow at the market is not only rich and effective, but also committed and caring.

What is new in today's farm initiatives is the distinctive contemporary manifestation of alternative relations offered by the farm markets. That is, mass distribution has disconnected producers from consumers to such an extent over the last few decades that reconnections (rather than connections) are sought. On the one hand, Karen relates that consumers who come to La Cassole farm are interested in food that is local and connected to their daily lives; she notes that consumers often disclose to her that they enjoy the intimacy and the connection with the producers responsible for the food they eat. On the other hand, producers are looking for new ways to continue producing food in a sector that is largely dominated by highly competitive and powerful business groups. Evident at the farm market is a sense of community enacted by the roles maintained by both the producer and the consumer in the local area. Producers provide farming and food knowledge and consumers rely on this knowledge and food in their understanding of the local food system.

Within the context of this reconnection, the term 'quality' is often mentioned by both the producers and the consumers at the farm. Karen relates: 'The aim of the farm is to 
produce natural good quality food however I don't like using words such as organic or chemical free which to me hold specific connotations.' In his research on mass distribution, Jacquiau suggests that food described as natural and traditional is now seen as a luxury in modern society and sold at high prices to people who are concerned for their health and ready to pay the extra cost. In addition, the mass market has recognised this trend and is filling shelves with organic products of their own, raising further issues about the mass production and locality of organic produce (Jacquiau 2000: 110). Indeed, Karen argues that if food is produced with as much care as possible so that the quality is not compromised, then the label 'organic' is superfluous and merely represents mass marketing and marketing trends. Consequently, the farm market for Karen is the articulation of alternative techniques that allow farmers to produce quality food that is affordable to the general public without coming across as a luxury product for the affluent.

Quality for Karen and some of the other producers at the farm market is linked to the concept of locality, and thus aligns with research into other locales. Winter's empirical work in England and Wales shows that the reasons given for the purchase of local products commonly reflected an interest in supporting local farmers and the local economy, with some emphasis also given to taste or freshness and local knowledge of the food's provenance (2003: 29). The association of quality and local provenance is also consistent with the findings of Holloway and Kneafsey (2004) from interviews with consumers at a farmers' market. They suggest that 'consumers make assumptions about the quality and freshness of the products simply because of the consumption context' (292). DuPuis and Goodman warn, however, that the local is not an innocent term, observing that it can provide the ideological foundations for reactionary politics and nativist sentiment. They thus call for a closer examination of 'the local' of local food systems in order to reveal the 'ambiguities and subtleties' of the ideas of 'localness' and 'quality’ (2005: 360). The notion of quality is also contested by Winter who argues that quality is 'socially constructed and the way it is measured and signified is constantly subject to change and adaptation as its key constitutive concepts, such as authenticity, health, tradition, taste, are themselves renegotiated' (2003: 25). I agree with the many recent critiques that call for a closer examination of terms used in alternative food research such as 'local' and 'quality' in order to better understand the meaning of these concepts but nonetheless need to acknowledge that these terms are used often by the 
producers at La Cassole farm. On market day at the farm, Karen makes a point of outlining the local origin of the cheese she sells. The baker at the bread stand describes the traditional types of ancient grains harvested by her farm and used in the bread she sells. The flyer on her table depicts images of bakers using heritage methods of baking. The wine grower stresses that her wine has a regional classification and emphasises the local methods used in her wine making. This form of local knowledge of food not only expresses a sense of territorial identity. It also conveys what Bowen and De Master identified as 'political and oppositional' meaning with regard to local food initiatives in Europe (2011: 17). Their analysis emphasises the cultural heritage of food products as a conscious response to the standardising and industrialising tendencies of globalisation and suggests that localisation is not only a way of counteracting industrialisation but also a way of enhancing rural livelihoods and preserving European heritage. Bessière's (1998) and Barham's (2003) research on local food initiatives further support this by showing that local actors re-appropriate and revalorise what has been lost by promoting and protecting specific practices and skills, while also helping to create and innovate, thus enabling producers to take some economic control of the food distribution system today. Concepts like terroir and heritage can be seen to reflect a conscious and active social construction of the present 'to recover and revalorize elements of the rural past to be used in asserting a new vision of the rural future' (Barham 2003: 132).

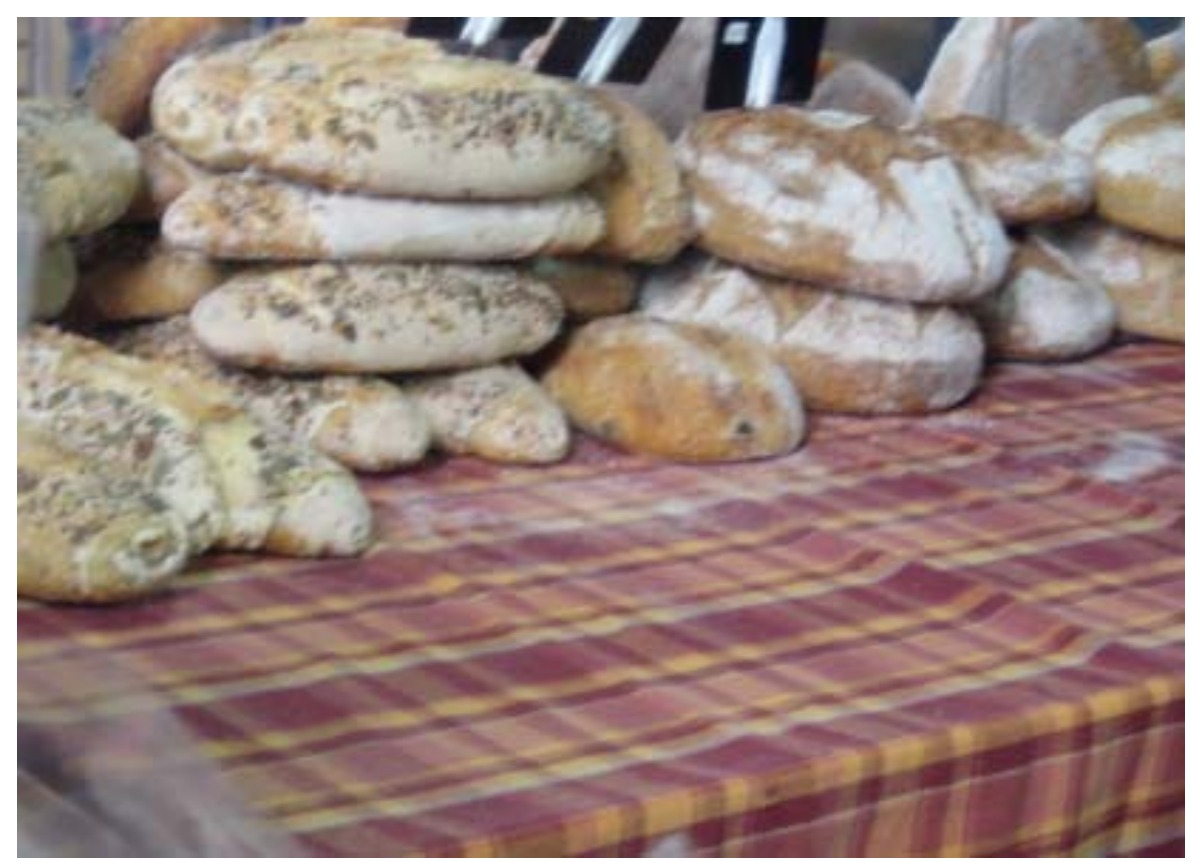

Figure 4. Food and heritage: bread available at La Cassole farm using ancient grains and traditional methods (C) A. Giovanangeli. 


\section{Concluding remarks}

The case study of La Cassole farm suggests that shifts in relations and strategies in specific French food initiatives are taking place in similar ways to the observations made in alternative food network research in other Western states such as the USA and the UK. In terms of social movement analysis, these initiatives could be considered as sites of collective action, foregrounding the struggles faced by local producers in the context of food distribution used by mass food retailing to secure economic gain and power in the food sector. The emergence and significance of alternative practices of food production and distribution at La Cassole farm provide a consciousness raising narrative, drawing producers and consumers together around a collective identity based on community and locality. Evidence collected in this case study suggests that the farm market initiative can be viewed as a creative and innovative performance that questions mainstream food practice and offers insight into the organisation and understanding of food production and distribution. At each level of performance and meaning making the processes forming and transforming collective beliefs take place in different ways through the diffusion of information and meaning construction, and through discussion of producers and consumers of the collective network. Collective thinking is formed as a result of the interpersonal interaction taking place in the farm market context whereby networks and friendship groups are created. While we need to be cautious about and examine further the meaningfulness of terms in alternative food discourse, such as 'local' and 'quality,' evidence collected at La Cassole farm suggests that cultural performances embedded in this local food initiative emerge in opposition to the mass industrialisation of agriculture and thus enact new ideas of innovation and the sharing of knowledge, which in turn may lead to cultural change in the meaning construction of food.

\section{Reference List}

Allen, P., FitzSimmons, M., Goodman, M., \& Warner, K. 2003, 'Shifting Plates in the Agrifood Landscape: The Tectonics of Alternative Agrifood Initiatives in California,' Journal of Rural Studies, vol. 19: 61-75.

Association pour le maintien d'une agriculture paysanne website. Online available: http://www.reseauamap.org/ [Accessed 2 November 2012].

Barham, E. 1997, 'Social Movements for Sustainable Agriculture in France: A Polanyian Perspective,' Society and Natural Resources: An International Journal, vol. 10, no. 3: 239-49.

Barham, E. 2003, 'Translating terroir: The Global Challenge of French AOC Labeling,' Journal of Rural Studies, vol. 19: 127-38.

Bartoli, G., Bové, J. \& Manguy, Y. 2003, La Confédération paysanne. Eden, Paris. 
Beardsworth, A., \& Keil, K. 1997, Sociology on the Menu: An Invitation to the Study of Food and Society. Routledge, London.

Bessière, J. 1998, 'Local Development and Heritage: Traditional Food and Cuisine as Tourist Attractions in Rural Areas,' Sociologia Ruralis, vol. 38: 21-34.

Bové, J. \& Luneau, G. 2000, Nous, Paysans. Hazan, Paris.

Bové, J. \& Dufour, F. 2001, Le Monde n'est pas une marchandise: des paysans contre la malbouffe. La Découverte, Paris.

Bové, J. \& Luneau, G. 2001, Paysan du Monde. Fayard, Paris.

Bové, J. \&, Luneau, G. 2012, Changeons de cap, changeons de Pac: Vers une agriculture paysanne au service des citoyens. Editions alternatives, Paris.

Bowen, S. \& De Master, K. 2011, 'New Rural Livelihoods or Museums of Production? Quality Food Initiatives in Practice,’ Journal of Rural Studies, vol. 27: 73-82.

La Cassole farm website. Online available: http://fermedelacassole.typepad.fr/ [Accessed 2 November 2012].

Chesters, G. \& Welsh, I. 2011, Social Movements: The Key Concepts. Routledge, London.

Davies, L. 2010, 'French Farmers Bring Rural Reality to Champs Elysées,' The Guardian, 23 May. Online available: http://www.guardian.co.uk/world/2010/may/23/french-farmers-champs-elysees [Accessed 10 June 2012].

Drive Fermier website. Online available: http://www.drive-fermier.fr/33/qui-sommes-nous/ [Accessed 26 March 2013].

DuPuis, M. \& Goodman, D. 2005, 'Should We Go "home” to Eat? Toward a Reflexive Politics of Localism,’ Journal of Rural Studies, vol. 21: 359-71.

Ekelund, L., \& Jönsson, H. 2011, 'How Does Modernity Taste? Tomatoes in the Societal Change from Modernity to Late modernity,' Culture Unbound, vol. 3: 439-45.

'EU Calls Milk Crisis Meeting for Oct 5,' 2009, EUbusiness online news, 23 September. Online available: http://www.eubusiness.com/news-eu/farm-milk-price-meet.lf/ [Accessed 14 June 2012].

European Commission, 2012, Agriculture and Rural Development, Glossary. Online available: http://ec.europa.eu/agriculture/glossary/ [Accessed 26 March 2013]).

Goodman, D. 2010, 'Place and Space in Alternative Food Networks. Connecting Production and Consumption,' in Consuming Space. Placing Consumption in Perspective, (eds) M. K. Goodman, D. Goodman \& M. Redclift. Ashgate, Farnham, UK: 189-211.

Holloway, L., \& Kneafsey, M. 2004, 'Producing-Consuming Food: Closeness, Connectedness and Rurality,' in Geographies of Rural Cultures and Societies, (eds) L. Holloway and M. Kneafsey. Ashgate, London, 262-82.

INSEE (Institut National de la Statistique et des Études Économiques). Online available: http://www.statistiques-locales.insee.fr/FICHES/DL/DEP/38/COM/DL_COM38381.pdf [accessed 14 June 2012].

Jacquiau, C. 2000, Les coulisses de la grande distribution. Albin Michel, Paris.

Johnston, H., \& Klandermans, B. 1995, 'The Cultural Analysis of Social Movements,' in Social Movements and Culture, Social Movements, Protest, and Contention, (eds) H. Johnston \& B. Klandermans. University of Minnesota Press, Minneapolis: 3-24.

Johnston, H. 2009, 'Protest Cultures: Performance, Artifacts, and Ideations,' in Culture, Social Movements, and Protest, (ed) H. Johnston, Ashgate, Farnham, UK: 3-29.

Kneafsey, M., Cox, R., Holloway, L., Dowler, Venn, E. \& Tuomainen, H. 2008, Reconnecting Consumers, Producers and Food. Berg, Oxford.

'Les Amaps poussent toujours' 2012, SudOuest, 28 April: 18-19.

Massey, D. 2005, For Space. Sage, London.

Peters, C. J., Bills, N. L., Lembo, A. J., Wilkins, J. L., \& Fick, G. W. 2008, 'Mapping Potential Foodsheds in New York State: A Spatial Model for Evaluating the Capacity to Localize Food Production,' Renewable Agriculture and Food Systems, vol. 24, no. 1: 72-84.

Potter, C. \& Tilzey, M. 2005, 'Agricultural Policy Discourses in the European Post-Fordist Transition: Neoliberalism, Neomercantilism and Multifunctionality,’ Progress in Human Geography, vol. 29, no. 5: 581-600.

Sage, C. 2003, 'Social Embeddedness and Relations of Regard: Alternative "Good Food” Networks in South-west Ireland,' Journal of Rural Studies, vol. 19: 47-60.

'Sept supermarchés visés par des attentats en Corse’ 2012, le Figaro, 10 September. Online available: http://www.lefigaro.fr/actualite-france/2012/09/10/01016-20120910ARTFIG00374-septsupermarches-vises-par-des-attentats-en-corse.php [Accessed 2 November 2012].

Snow, D. 2004, 'Social Movement as Challenges to Authority. Resistance to an Emerging Conceptual Hegemony,’ Reseach in Social Movements, Conflicts and Change, vol. 25: 3-25. 
Staggenborg, S. 2011, Social Movements. Oxford University Press, New York \& Oxford.

Starr, A. 2010, 'Local Food: A Social Movement?’ Cultural Studies $\leftrightarrow$ Critical Methodologies, vol. 10, no. 6: 479-90.

Tarrow, S. 1998, Power in Movement, Social Movements and Contentious Politics, $2^{\text {nd }}$ ed. Cambridge University Press, Cambridge.

Tilly, C. \& Wood, L. 2013, Social Movements 1768-2012, $3^{\text {rd }}$ ed. Paradigm Publishers, London.

Tregear, A. 2011, 'Progressing Knowledge in Alternative and Local Food Networks: Critical Reflections and a Research Agenda,' Journal of Rural Studies vol. 27: 419-30.

Université populaire du goût website. Online available: http://upa.michelonfray.fr/ [Accessed 2 November 2012].

Willging, J. 2008, 'Of GMOs, McDomination and Foreign Fat: Contemporary Franco-American Food Fights,' French Cultural Studies vol. 19: 199-226.

Winter, M. 2003, 'Embeddedness, the New Food Economy and Defensive Localism,' Journal of Rural Studies vol. 19: 23-32.

Zimmer, M. 2011, 'Les AMAP en France: entre consommation de produits fermiers locaux et nouvel ordre de vie,' in La consommation critique. Mouvements pour une alimentation responsable et solidaire, (ed.) G. Pleyers. Desclé de Brouwer, Paris: 47-67. 